\title{
Comparing Geothermal Heat Pump Systems to Conventional HVAC Systems in Hot and Humid Climates
}

\author{
Claudia Duran de Tapia ${ }^{1}$, Christofer M. Harper ${ }^{2, *}$ \\ 1. Louisiana State University, Baton Rouge, LA, 70803, USA \\ 2. Colorado State University, Fort Collins, CO, 80523, USA \\ E-mail: cduran7@lsu.edu; chris.harper@colostate.edu (Corresponding Author)
}

Received: 5 January 2021; Accepted: 5 March 2020; Available online: 10 April 2021

\begin{abstract}
Geothermal heat pump (GHP) systems are more concentrated to moderate climate regions, although the potential for GHP systems in hot and humid climates is possible as past research efforts have demonstrated this using simulations and commercial case examples. This research investigates the use of residential GHP systems for the hot and humid climate found in southern Louisiana. The authors collected field performance information, including initial system cost, and electricity consumption and costs from two residential case studies in which each case included one home with a conventional heating and cooling system and one home with a GHP system. Using a comparative analysis and analysis of variance, results illustrate that initial cost of GHP system in the first case was $\$ 13,285$ more and the second case was $\$ 17,588$ more than the installation costs of a conventional system. Further, the GHP system payback period depends on the whether the design uses a horizontal or vertical ground loop, and the designer and contractor's quality and experience in performing the GHP work as the first case resulted in a payback period of 70 years while the second case had a payback period of only seven years. Findings show that when an appropriate installation occurs, GHP system can save consumption and energy costs for residential homes in hot and humid climates.
\end{abstract}

Keywords: Renewable building energy systems; Geothermal heat pumps; Energy efficiency; Comparative analysis; Analysis of variance.

\section{Introduction}

Heating, ventilation, and air conditioning (HVAC) systems are typically one of the major components of building energy consumption, accounting for $42 \%$ of residential primary energy use and 32\% of commercial building primary energy use [1]. Furthermore, the U.S. Energy Information Administration states that the building sector consumes $40 \%$ of total primary energy and consumes $74 \%$ of all electricity usage, which constitutes a large portion of the cost to operate and maintain a facility [2]. Yet, a large fraction of energy delivered to buildings becomes wasted because of inefficient building technologies and systems [3]. To improve energy efficiency and savings, modern technologies and renewable energy systems must be explored, particularly on the HVAC side of energy consumption. The U.S. Department of Energy Building Technologies Program identified geothermal heat pumps (GHPs) as one such high-impact technology that can reduce energy consumption and peak electrical demand in residential and commercial buildings [4,5].

GHPs, also known as Ground-Source Heat Pumps, typically result in less annual energy consumption when compared to conventional systems. Of the portion of energy cost associated with the HVAC system, the consumption savings is in the range of $30 \%$ to $60 \%$ over common residential HVAC systems such as an air-source heat pumps or forced air furnace with split-system air conditioning [5-7]. While GHPs are more energy efficient compared to air-source heat pumps and forced-air furnace systems, previous research studies identified key barriers that inhibit GHP widespread industry growth including 1) High capital cost for ground loops, 2) Low market awareness, 3) lack of knowledge in GHP benefits, and 4) Infrastructure limitations including a limited number of qualified and experienced installers [8-11]. In addition, while GHPs are applicable to many types of commercial and residential facilities, these units are typically sized based on the cooling load demands, and in hot and humid climate zones they are typically oversized for heating loads and may not provide the same efficiencies of a GHP system with lower cooling loads [10-12].

Many studies exist on geothermal energy, GHPs, and the installation and payback period of these systems for commercial and residential facilities [5-7] with many focusing on simulations of GHP systems [7,8,13] or field performance for GHPs in climates with high heating demand [14]. Limited information is known about the costs and payback period of GHPs for residential homes in hot and humid climates using field performance data. Since 
GHP field performance can vary among similar systems at different location, the lack of field performance investigations limits the potential use of these renewable energy systems for climates that experience high cooling demand [5]. Therefore, the purpose of this study is to conduct a comparative analysis of the electricity consumption and cost of GHP systems when compared to HVAC systems installed in existing residential buildings in Southern Louisiana. The study investigates the benefits and challenges of installing and using GHPs in climate zones that experience higher cooling loads than heating loads while analyzing electricity consumption and cost data to find electricity cost savings and the payback period. The outcomes show that with proper installation and use, a GHP system is a viable option for residential homes in hot and humid climates.

\section{Background}

The difference between GHP and conventional heating and cooling systems for residential applications is that instead of rejecting heat from building spaces to the ambient air (in cooling mode) and extracting heat from fossil fuel combustion or electricity (in heating mode), a GHP rejects heat to or extracts heat from various ground resources [15]. When professionally designed and installed, GHPs have the capabilities of producing reductions in energy use and extending equipment life since they have limited exposed outdoor equipment [11]. It is common for the GHP to last 20-25 years while the ground loop tends to have a lifespan of 50 years [6,7].

Although GHPs have a higher initial investment compared to conventional systems due to the additional ground and site work and system components (heat pump, connections, and distribution system), the overall performance tends to be more favorable. Cooperman et al. [4] noted that ground source heat pumps can consume up to 50\% less energy than conventional HVAC equipment. The United States Department of Energy and the United States Environmental Protection Agency (EPA) are two government institutions that categorize GHPs as the most efficient, comfortable, and environmentally friendly technology for space heating and cooling [5]. The additional installation costs for a GHP are claimed to be returned in the form of energy savings within five to ten years as operating costs for GHPs are generally low since energy usage is mainly electricity for operating the GHPs and circulation pumps and natural gas is no longer required [16]. Cui et al. [7] and Bolling and Mathias [17] found the payback period for various GHP systems to be in the range of four to more than 15 years, while Cooperman et al. [4] found that high-efficiency ground source heat pump systems for residential homes located in the southern United States result in a payback period of about 15 years to more than 30 years depending on the system and installation.

\subsection{Professional GHP certification standards}

Proper professional licenses or certifications are requirements in the U.S. to design and install GHP systems. It is required that GHP system design must be reviewed and stamped by a Professional Engineer, and in some states, GHP engineers and designers they must also be accredited by the International Ground Source Heat Pump Association (IGSHPA) as Certified Geo Exchange Designers (CGD) [18]. Properly sizing the closed-loop geothermal heat exchanger is particularly important as this component represents a significant share of the overall system cost and impacts the performance of the system. The sizing methodology needs to account for many factors, including heat rejection and extraction loads, the physical layout of the loop, the thermal properties of soil/rock formation at the job site, and the thermal properties of the grouting material [18]. Accordingly, proper installation of GHP systems is essential in order to achieve appropriate installation costs, high performance that results in consumption savings, and longevity of the system that reduces operation and maintenance costs, and therefore, it is recommended to choose only qualified and highly experienced GHP contractors [19].

\subsection{Key barriers to GHP use}

Initial cost and long payback periods limit GHP system acceptance in many markets and regions [10]. Currently in United States commercial markets, GHPs are primarily used for institutional facilities (e.g., federal, state, and local governments, K-12 schools, colleges, and universities) and large commercial campuses that take the lifecycle view of a GHP system. In residential markets, GHPs are limited to a subset of newly constructed homes that an owner plans to occupy long term and thus wants to equip it with an optimal system, and for retrofitting homes in which an owner plans to occupy the premises long enough to justify the investment [15].

While ground loop cost appears to be a major reason for higher initial cost, there are many factors that influence the installation costs and performance of GHPs such as the size of the ground loop, the depth of the ground loop, capacity of the heat pump, heat transfer fluid, flow rate, pipe size, spacing of the horizontal loop, and soil type $[7,20]$. Without knowledge of, and experience with GHP systems and equipment, installers are hesitant to advertise and sell such systems. Furthermore, inexperienced designers tend to oversize GHP systems and add excessive backup capacity to provide a larger safety margin but doing so unnecessarily increases their costs to the consumer, which lessens their interests in such systems [15]. 
The lack of public awareness in non-conventional HVAC systems directly leads to low motivation to invest in GHP systems. In order to educate the public on the benefits of GHP for heating and cooling, actual performance data and energy consumption costs for GHPs needs to be collected and shared to show the performance of GHP systems and comparing this performance and cost savings to conventional HVAC systems. Yet, most GHP performance studies are geared toward applications in cooler and drier climates [14,20-23] with only limited studies focusing on applications in hot and humid climate zones that require much higher cooling demands [8,2426].

Reductions in GHP system cost, improvements in installation quality, greater competition, and improved market penetration have occurred primarily in regions that have installed and used GHPs for many years. The first cost of GHPs in other regions that do not have established contractors and designers is often higher due to lack of knowledge and experience in the market. Furthermore, in the current fragmented design-installer approach in which there are several designers completing portions of the full design that is handed off to other parties to be installed, GHP designers and installers tend to reduce the size of the system in hopes of making the systems more financially attractive [10]. Reducing the size of a GHP and associated loop can have negative impacts such as a lack of redundancy in the system and potential buildup of heat during the cooling season, which impacts the energy consumption savings as the system runs longer.

While part of this barrier can be overcome through greater consumer education and awareness of energy and cost saving benefits by demonstrating the energy and cost savings through case studies, initial-cost barriers must also be addressed [9]. Recommendations are to concentrate on reducing the cost of primary components (e.g., heat pumps, indoor installation, and pumps) instead of overemphasizing low-cost loops at the expense of efficiency.

\subsection{Use of GHP in hot and humid climates}

In the 1990s, the Oak Ridge National Laboratory performed an evaluation of 4,003 homes for military families retrofitted with GHP systems at Fort Polk, Louisiana, which experiences a hot and humid climate [24]. The analysis found that the community of homes can save upwards of $42 \%$ of the pre-retrofit community electricity consumption due to the GHPs, translating to electricity cost reduction, and with the retrofit, natural gas is no longer used for heating purposes, saving $100 \%$ of the pre-retrofit community consumption. In addition, this analysis developed an improved method of predicting energy savings as well as documented design methods for vertical borehole loop heat exchangers to calibrate the system based on an engineered model [24]. Overall, this study showed that GHPs can be useful systems in climates that experience higher cooling loads than heating loads.

In a study by Zhu et al. [8], the researchers used simulations developed through the TRNSYS/EnergyPlus to model residential homes located in hot and humid climates of Florida. A baseline model was established and compared to new construction and retrofitted homes models using GHP systems. The models helped to develop a cost-benefit tool and performed life cycle cost analysis based on the simulated models. The findings from this study showed that overall GHPs have the potential to work in hot and humid climates, consume less energy when compared to conventional air-source heat pumps, closed loop GHP systems save more energy than open loop systems, and the more complex a GHP system is for a hot and humid climate, the lower the energy savings realized. However, the study also found that applications of GHPs in hot and humid climates have more uncertainty in terms of the performance and experience longer payback periods than GHPs installed in more moderate climate regions [8].

Although simulation programs support data collection and analysis, assumed parameters used in simulations do not always coincide with reality. Although assumptions are valid in simulations, they may not occur in real life, such as the uniform placement of boreholes, perfectly constant weather (e.g., no saturation or heat accumulation over periods of time) and overlooking human error during installation. However, the information from simulations of GHPs in hot and humid climates is important, and further research efforts need to focus more on in-field performance and cost analyses for GHP systems [14].

\section{Methodology}

The research objective is to determine the electricity consumption and cost performance, as well as the payback period for geothermal heat pump systems using data collected from residential homes in southern Louisiana. To achieve this objective, the focus of the study is on the following questions:

Question 1: How do geothermal heat pump systems perform in terms of electricity usage and cost in hot and humid climates for residential homes when compared to conventional HVAC systems?

Question 2: What is the payback period for installing a GHP system in residential homes in hot and humid climates?

The following sections outline the literature review and the case studies conducted in this research project along with the analyses used after data collection. 


\subsection{Conduct literature review}

The authors investigated the status of energy consumption across the building sector and found GHPs to have the potential to increase the efficiency of energy usage in residential buildings. The market development of GHPs was also investigated, especially in regions with hot and humid climates. From there, key barriers were identified and previous research work that addressed key barriers, such as lack of knowledge towards GHPs, were reviewed.

\subsection{Develop case study protocol}

A case study protocol was created and refined based on the intent of this research, using as reference the Analysis of Maintenance and Service Costs in Commercial Building Geothermal Systems prepared by Cane et al. [27] for the Geothermal Heat Pump Consortium, and Analysis of Energy, Environmental and Life Cycle Cost Reduction Potential of Ground Source Heat Pumps (GSHP) in Hot and Humid Climate, prepared by Tao and Zhu [28] from Florida International University for the U.S. Department of Energy. The protocol provided a method to collect data from residential GHP and conventional HVAC systems.

\subsection{Conduct case studies}

The data collection process utilized case studies of residential homes using geothermal heat pump systems for heating and cooling purposes found in southern Louisiana. The data collection process included identifying potential homes and homeowner participants, contacting potential participants, gathering geothermal system data from the homes with geothermal heat pump systems and from homes with similar characteristics but includes a conventional HVAC system, and analyzing the electricity consumption and cost data from each case. Figure 1 provides the monthly average ambient and ground temperatures for New Orleans, Louisiana, the location of the case study homes.

The case study protocol prepared includes the following sections of data to collect from the GHP homes and the conventional HVAC homes:

1) Building information: Basic information of the residence such as location, type of residence, year constructed, floor area, number of floors, number of occupants, along with the specific details of the framing and insulation used for walls, roofs, and floors, as well as details on the windows of the structure.

2) GHP or conventional HVAC system general information: HVAC installation date, type of system, type of loop along with the details of the system such as header diameters and length of pipe installed.

3) GHP or conventional HVAC system installation cost: A breakdown of the installation costs for the system: ground loop costs (for the GHP systems) and system costs. Each of the cost breakdowns includes the materials and equipment, the costs of the materials and equipment, and labor costs to install the system.

4) Available metered data: The electricity usage data $(\mathrm{kWh})$ for each home for use in the analyses of electricity consumption, cost, and payback period.

Additionally, follow up in-person meetings took place to review the case study protocol and to collect any other needed information for this study. On-site visits supported additional information collection of the building and helped to obtain a better understanding of the operation and the settings of the GHP systems. In addition to the cost data provided by the homeowners, local mechanical contractors provided cost quotes for reference.

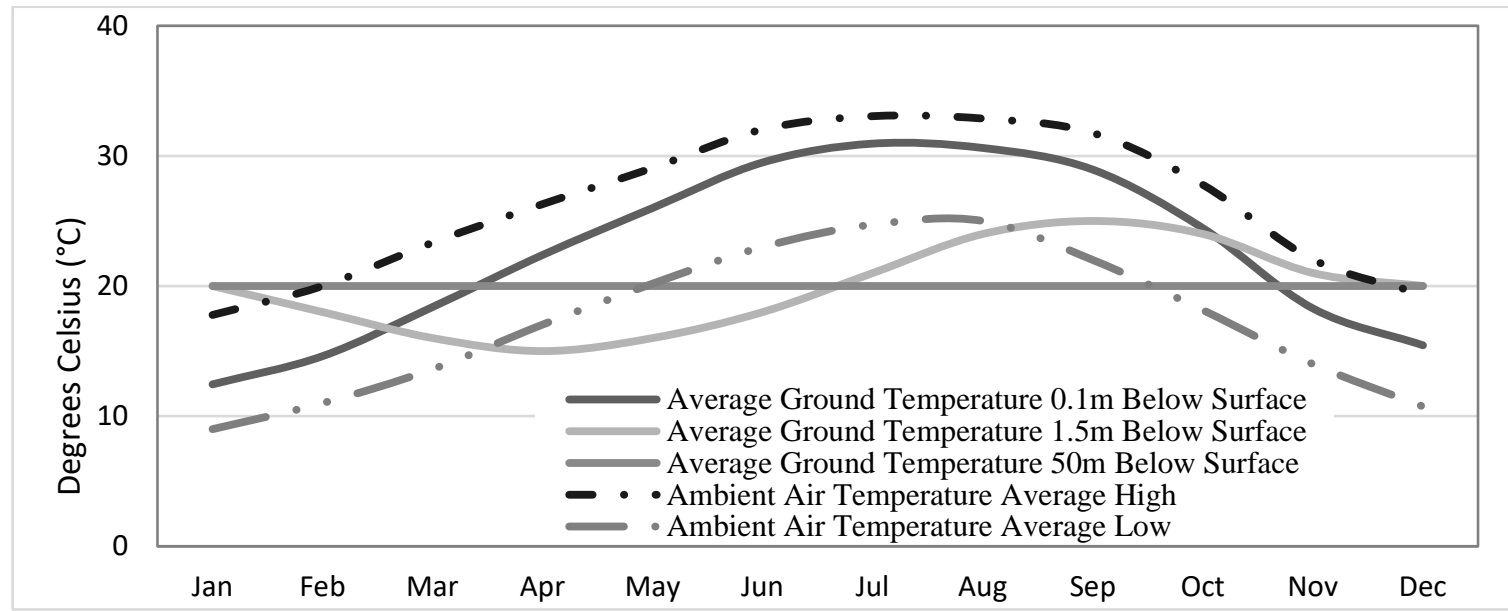

Figure 1. Monthly average ground and ambient temperatures for New Orleans [29,30]

\subsection{Analyze case study data}

The first step in the analysis was to determine if the collected data was statistically the same. To do this, an analysis of variance (ANOVA) was implemented. The analysis included the following steps: 
1) Determine the descriptive statistics for each sample (mean, standard deviation, variance, minimum, maximum, and range).

2) Test data for normality using MVP Stats statistical program.

3) Test for homogeneity of variance in SPSS using Levene's Statistic.

4) Test the mean values using a one-way ANOVA (established homogeneity of variance) or Welch ANOVA (lack of homogeneity of variance) in SPSS.

To obtain the electricity cost, electricity usage had to be converted to U.S. dollars by multiplying the electricity usage (in kilowatt-hours, kWh) by the monthly retail price for residential electricity in Louisiana (cents/kWh). Table 1 shows the monthly retail price of residential electricity per kWh in Louisiana.

Table 1. Monthly retail price of electricity for residences in Louisiana from 2012 to 2017 [31]

\begin{tabular}{lcccccc}
\hline & $\mathbf{2 0 1 2}$ & $\mathbf{2 0 1 3}$ & $\mathbf{2 0 1 4}$ & $\mathbf{2 0 1 5}$ & $\mathbf{2 0 1 6}$ & $\mathbf{2 0 1 7}$ \\
\hline Jan & $\$ 0.082$ & $\$ 0.089$ & $\$ 0.086$ & $\$ 0.089$ & $\$ 0.087$ & $\$ 0.079$ \\
Feb & $\$ 0.084$ & $\$ 0.092$ & $\$ 0.089$ & $\$ 0.089$ & $\$ 0.087$ & $\$ 0.097$ \\
Mar & $\$ 0.084$ & $\$ 0.092$ & $\$ 0.093$ & $\$ 0.089$ & $\$ 0.094$ & $\$ 0.097$ \\
Apr & $\$ 0.084$ & $\$ 0.092$ & $\$ 0.102$ & $\$ 0.094$ & $\$ 0.094$ & $\$ 0.096$ \\
May & $\$ 0.085$ & $\$ 0.097$ & $\$ 0.103$ & $\$ 0.098$ & $\$ 0.095$ & $\$ 0.101$ \\
Jun & $\$ 0.080$ & $\$ 0.097$ & $\$ 0.101$ & $\$ 0.094$ & $\$ 0.092$ & $\$ 0.104$ \\
Jul & $\$ 0.084$ & $\$ 0.098$ & $\$ 0.102$ & $\$ 0.094$ & $\$ 0.093$ & $\$ 0.102$ \\
Aug & $\$ 0.083$ & $\$ 0.098$ & $\$ 0.099$ & $\$ 0.097$ & $\$ 0.097$ & $\$ 0.101$ \\
Sep & $\$ 0.086$ & $\$ 0.097$ & $\$ 0.098$ & $\$ 0.097$ & $\$ 0.097$ & $\$ 0.101$ \\
Oct & $\$ 0.087$ & $\$ 0.097$ & $\$ 0.097$ & $\$ 0.097$ & $\$ 0.095$ & $\$ 0.099$ \\
Nov & $\$ 0.084$ & $\$ 0.092$ & $\$ 0.089$ & $\$ 0.092$ & $\$ 0.094$ & $\$ 0.095$ \\
Dec & $\$ 0.085$ & $\$ 0.088$ & $\$ 0.093$ & $\$ 0.088$ & $\$ 0.094$ & $\$ 0.091$ \\
\hline
\end{tabular}

Following the ANOVA, the authors calculated the payback period for each case study. First, the average monthly electricity costs were calculated based on the collected data for both the GHP and conventional HVAC homes. Then, the difference between the conventional HVAC and GHP monthly electricity costs was calculated to find the monthly savings. Then, the annual average electricity cost savings was calculated by adding up the monthly electricity cost savings. Next, the difference in installation cost between the GHP and conventional HVAC system was calculated to determine the difference in initial costs for the GHP system when compared to a conventional HVAC system. Finally, payback period was then calculated by taking the difference in installation cost and dividing it by the annual electricity cost savings to find the payback period as the number of years until the homeowner "breaks even" on the additional costs to install the system and the savings realized in using the GHP system over the life of the system.

\section{Data collection}

This study collected technical and non-technical data from two homes with GHP systems, designated as GHP1 and GHP2, as well as one similar home to GHP1 with a conventional HVAC (CH) system installed, designated as CH1. For Case Study 2, CH2 is a home that had a conventional HVAC system installed, while GHP2 is the same home, but retrofitted with a GHP system, replacing the conventional HVAC system. Table 2 summarizes the HVAC system information for the GHP systems, while Table 3 outlines the conventional HVAC systems.

\subsection{Case study 1}

Case Study 1 includes GHP1 and CH1, both constructed by the same non-profit organization and are located next to one another in an area of New Orleans that was devastated by Hurricane Katrina. GHP1, initially constructed in 2008, is a two-story, three-bedroom single-family house built on a pile/pier foundation New Orleans, LA that has a total floor area of $118 \mathrm{~m}^{2}\left(1,258 \mathrm{ft}^{2}\right)$. The home is certified Platinum according to the U.S. Green Building Council's Leadership in Energy and Environmental Design (LEED). The home also has an energy rating certificate that shows a home energy rating system (HERS) index of 13, which means the home operates at $87 \%$ more efficiency than a conventional home.

CH1 is also a two-story, three-bedroom single-family house on pile/pier foundation built in 2009 in with a total floor area of $113 \mathrm{~m}^{2}\left(1,220 \mathrm{ft}^{2}\right)$. The residence received an energy rating certificate in 2010 , and it is rated with a HERS Index of 17 or $83 \%$ more efficient home than a conventional residence. $\mathrm{CH} 1$ uses a programmable thermostat for heating and cooling. The distribution system includes conventional ductwork for central distribution. Table 4 provides additional construction details for GHP1 and CH1 gathered from the plans and specifications provided by the homeowners. 
Table 2. GHP system information for the two residential homes used in the case studies

\begin{tabular}{|c|c|c|}
\hline & GHP1 & GHP2 \\
\hline \multicolumn{3}{|l|}{ Heat Exchanger } \\
\hline Type of loop & Closed Loop & Closed Loop \\
\hline Ground loop & $\begin{array}{l}\text { Horizontal Slinky - 291-meter } \\
\text { (954-foot) loop }\end{array}$ & $\begin{array}{l}\text { Vertical - } 5 \text { boreholes at a total } \\
\text { length } 381 \mathrm{~m}(1,250 \mathrm{ft})\end{array}$ \\
\hline Depth of loop & $\begin{array}{l}1.2-1.8 \text { meters }(4-6 \text { feet }) \\
\text { below ground level }\end{array}$ & $\begin{array}{l}\text { Each borehole is } 76.2 \mathrm{~m}(250 \mathrm{ft}) \\
\text { deep }\end{array}$ \\
\hline Backfill and grout material & Bentonite mixture & Bentonite mixture \\
\hline Spiral loop diameter & $1.2 \mathrm{~m}(4 \mathrm{ft})$ & NA \\
\hline Borehole diameter & NA & $11.4 \mathrm{~cm}(4.5 \mathrm{in})$ \\
\hline $\begin{array}{l}\text { Distance between } \\
\text { trenches/boreholes }\end{array}$ & $2.4 \mathrm{~m}(8 \mathrm{ft})$ & $1.2 \mathrm{~m}(4 \mathrm{ft})$ \\
\hline Ground loop pipe diameter & $1.9 \mathrm{~cm}(0.75 \mathrm{in})$ & $2.5 \mathrm{~cm}(1 \mathrm{in})$ \\
\hline Pipe material & cross-linked polyethylene (PEX) & High-density polyethylene (HDPE) \\
\hline Header size & $3.2 \mathrm{~cm}(1.25 \mathrm{in})$ & $5.1 \mathrm{~cm}(2.0 \mathrm{in})$ \\
\hline \multicolumn{3}{|l|}{ Geothermal Heat Pump } \\
\hline Manufacturer & WaterFurnace 5 Series & WaterFurnace 5 Series \\
\hline Heating Capacity & 7,620W (26,000Btuh) & 11,195W (38,200Btuh) \\
\hline Cooling Capacity & 10,509W (3.0 tons) & 14,888W (4.25 Tons) \\
\hline Flow Rate & 5.6 LPM/ton (1.5 GPM/ton) & 11.3 LPM/ton (3.0 GPM/ton) \\
\hline Heating Operation & $21^{\circ} \mathrm{C}\left(70^{\circ} \mathrm{F}\right)$ & $21^{\circ} \mathrm{C}\left(70^{\circ} \mathrm{F}\right)$ \\
\hline $\begin{array}{l}\text { Temperatures: Entering } \\
\text { Heating Operation } \\
\text { Temperatures: Exiting }\end{array}$ & $13-15^{\circ} \mathrm{C}\left(56-60^{\circ} \mathrm{F}\right)$ & $15-17^{\circ} \mathrm{C}\left(58-62^{\circ} \mathrm{F}\right)$ \\
\hline $\begin{array}{l}\text { Cooling Operation } \\
\text { Temperatures: Entering }\end{array}$ & $21^{\circ} \mathrm{C}\left(70^{\circ} \mathrm{F}\right)$ & $21^{\circ} \mathrm{C}\left(70^{\circ} \mathrm{F}\right)$ \\
\hline $\begin{array}{l}\text { Cooling Operation } \\
\text { Temperatures: Exiting }\end{array}$ & $29-32^{\circ} \mathrm{C}\left(85-91^{\circ} \mathrm{F}\right)$ & $25-28^{\circ} \mathrm{C}\left(77-83^{\circ} \mathrm{F}\right)$ \\
\hline COP & 4.1 & 4.0 \\
\hline EER & 19.3 & 19.3 \\
\hline
\end{tabular}

Table 3. Conventional HVAC system information for the two residential homes used in the case studies

\begin{tabular}{lcc}
\hline & CH1 & CH2 \\
\hline Manufacturer & Trane & York \\
System & Air-source heat pump & Split system air conditioning with electric radiation heating \\
Heating Capacity & $7,034 \mathrm{~W}(24,000 \mathrm{Btuh})$ & NA \\
Cooling Capacity & $10,551 \mathrm{~W}$ (3 Tons) & 14,068W (4 Tons) \\
HSPF & 8.5 & NA \\
COP & 2.9 & 2.5 \\
SEER & 15.3 & 16 \\
EER & NA & 13 \\
\hline
\end{tabular}

Table 4. Building shell information for GHP1 and CH1

\begin{tabular}{|c|c|c|c|c|}
\hline \multirow[b]{2}{*}{ Shell } & \multicolumn{2}{|l|}{ GHP1 } & \multicolumn{2}{|l|}{ CH1 } \\
\hline & Materials & Insulation & Materials & Insulation \\
\hline $\begin{array}{l}\text { Exterior } \\
\text { Walls }\end{array}$ & $\begin{array}{l}\text { Wood siding, moisture } \\
\text { membrane, OSB sheathing, } \\
\text { flashing, } 5.1 \mathrm{~cm} \text { by } 15.2 \mathrm{~cm} \text { ( } 2 \mathrm{in} \\
\text { by 6in) wood studs, insulation }\end{array}$ & $\begin{array}{l}5.1 \mathrm{~cm}(2 \mathrm{in}) \text { foil } \\
\text { faced, U- } \\
\text { value }=0.44\end{array}$ & $\begin{array}{l}\text { Wood siding, moisture } \\
\text { membrane, OSB sheathing, } \\
\text { flashing, } 5.1 \mathrm{~cm} \text { by } 15.2 \mathrm{~cm}(2 \mathrm{in} \\
\text { by 6in) wood studs, insulation }\end{array}$ & $\begin{array}{l}\text { Spray foam, } \\
\text { U-value }=0.28\end{array}$ \\
\hline Roof & $\begin{array}{l}\text { Engineered trusses, sheathing, } \\
\text { roofing membrane, insulation, } \\
\text { roof sheathing, metal roof panels }\end{array}$ & $\begin{array}{l}8.9 \mathrm{~cm}(3.5 \mathrm{in}) \\
\text { soy-based spray } \\
\text { foam, U- } \\
\text { value }=0.21\end{array}$ & $\begin{array}{l}\text { Engineered trusses, sheathing, } \\
\text { roofing membrane, insulation, } \\
\text { roof sheathing, metal roof } \\
\text { panels }\end{array}$ & $\begin{array}{l}\text { Spray foam, } \\
\text { U-value }=0.21\end{array}$ \\
\hline Windows & $\begin{array}{l}\text { Low-E, wood, hurricane impact } \\
\text { glass }\end{array}$ & $\begin{array}{l}\text { U-value }=1.87 \\
\text { SHGC }=0.30\end{array}$ & $\begin{array}{l}\text { Low-E, wood, hurricane impact } \\
\text { glass. }\end{array}$ & $\begin{array}{l}\text { U-value }=1.99 \\
\text { SHGC }=0.32\end{array}$ \\
\hline
\end{tabular}


GHP1 uses a geothermal heat pump system to supply heating and cooling to the house. The installation of the HVAC system was completed in January 2009. The geothermal heat pump system uses a coiled, closed-loop ground source heat exchanger. Due to the proximity of the construction site to a levee and a high water table in the area, the geothermal pipes are buried horizontally in the backyard in a slinky loop configuration between four and six feet below the ground surface.

The system has a desuperheater in line from the water heater. The desuperheater is used with the GHP system as an added loop in which a circulating pump pulls unheated water through the heat exchanger to pick up excess heat that is then pumped into the water heater so that wasted heat is re-used for domestic hot water rather than deposited back into the ground. Additionally, as a backup, the system has a cooling tower that runs an additional loop for additional heat sink capacity and uses water heating to dissipate excess heat to heat the domestic water for the home.

\subsubsection{Installation cost data}

The GHP1 homeowner provided billings and invoices for the materials, maintenance, and installation cost of the GHP system. The installation and equipment cost of the air-source system in CH1 includes cost data as provided by the homeowner along with the average cost calculated from three quotes requested from three different mechanical contractors located in New Orleans. Table 5 summarizes the cost of the GHP system in GHP1 and the conventional system in CH1. The installation cost of the GHP system for GHP1 is $\$ 232.49$ per $\mathrm{m}^{2}\left(\$ 21.64\right.$ per $\left.^{2} \mathrm{ft}^{2}\right)$ based on the total installation cost and the $118 \mathrm{~m}^{2}\left(1,268 \mathrm{ft}^{2}\right)$ floor area of GHP1. The total installation cost for the GHP is $\$ 14,149$ more than the conventional system.

Table 5. Installation cost for Case Study 1 GHP System (GHP1) Total Cost

\begin{tabular}{lr}
\hline Equipment & \\
Geothermal Heat Pump (Water-to-air heat pump) & $\$ 9,890$ \\
Water pump & $\$ 290$ \\
Distribution system & $\$ 3,100$ \\
System controls & $\$ 2,280$ \\
Cooling tower & $\$ 1,116$ \\
Labor & Included above \\
$\quad$ Equipment Total & $\$ 17,216$ \\
\hline Ground Loop & $\$ 2,738$ \\
$\quad$ Excavation & $\$ 400$ \\
Grouting & $\$ 7,620$ \\
$\quad$ Pipe, Fittings, and Headers & Included above \\
Labor & $\$ 10,758$ \\
$\quad$ Ground Loop Total & $\mathbf{\$ 2 7 , 4 3 4}$ \\
\hline GHP1 SYSTEM TOTAL & Total Cost \\
\hline & $\$ 5,146$ \\
Equipment (air-source heat pump) & $\$ 3,100$ \\
Distribution System & $\$ 1,284$ \\
System Controls & $\$ 3,755$ \\
Labor & $\mathbf{\$ 1 3 , 2 8 5}$ \\
CH1 SYSTEM TOTAL & System (CH1)
\end{tabular}

\subsubsection{Consumption and cost data}

The energy usage data collected for GHP1 and CH1 included data from the systems' monitoring and tracking system as well as monthly energy bills. The monitoring system also provided information on the ambient temperature of the home, which was kept between $20.5^{\circ} \mathrm{C}\left(68^{\circ} \mathrm{F}\right)$ and $22.8^{\circ} \mathrm{C}\left(73^{\circ} \mathrm{F}\right)$ for $\mathrm{GHP} 1$ and between $20^{\circ} \mathrm{C}$ $\left(68^{\circ} \mathrm{F}\right)$ and $22.2^{\circ} \mathrm{C}\left(72^{\circ} \mathrm{F}\right)$ for $\mathrm{CH} 1$ throughout the year. The data collected includes 40 months of consumption (in kWh) and cost, from January 2014 through April 2017 for GHP1 and 52 months of consumption and cost data, from January 2013 to April 2017 for CH1. Table 6 and Table 7 present the collected electricity data for GHP1 and $\mathrm{CH} 1$. The cost amounts included have been normalized to 2017 prices using inflation values from the U.S. Bureau of Labor Statistics, with 6.8\% inflation for 2012, 5.2\% for 2013, 3.5\% for 2014, 3.4\% for 2015, and 2.1\% for 2016. The total electricity consumption from January 2014 to April 2017 for GHP1 is 9,832 kWh and the total usage cost is $\$ 913.11$. The total electricity consumption from January 2013 to April 2017 for CH2 is 98,345 kWh with a total electricity cost of $\$ 9,532.22$. 
Table 6. Electricity Consumption and Cost for GHP1

\begin{tabular}{|c|c|c|c|c|c|c|c|c|c|c|}
\hline & \multicolumn{2}{|c|}{2013} & \multicolumn{2}{|c|}{2014} & \multicolumn{2}{|c|}{2015} & \multicolumn{2}{|c|}{2016} & \multicolumn{2}{|c|}{2017} \\
\hline & kWh & Cost (\$) & kWh & Cost (\$) & kWh & Cost (\$) & kWh & Cost (\$) & kWh & Cost (\$) \\
\hline Jan & & & 234 & $\$ 20.76$ & 231 & $\$ 21.31$ & 241 & $\$ 20.92$ & 226 & $\$ 17.42$ \\
\hline Feb & & & 296 & $\$ 27.12$ & 424 & $\$ 39.15$ & 364 & $\$ 31.44$ & 231 & $\$ 22.11$ \\
\hline Mar & & & 245 & $\$ 23.49$ & 328 & $\$ 30.29$ & 247 & $\$ 23.02$ & 144 & $\$ 13.62$ \\
\hline Apr & & & 154 & $\$ 16.28$ & 172 & $\$ 16.63$ & 138 & $\$ 12.92$ & 161 & $\$ 15.05$ \\
\hline May & & & 123 & $\$ 13.16$ & 168 & $\$ 17.02$ & 167 & $\$ 15.82$ & & \\
\hline Jun & & & 212 & $\$ 22.19$ & 207 & $\$ 20.08$ & 147 & $\$ 13.45$ & & \\
\hline Jul & & & 218 & $\$ 22.98$ & 302 & $\$ 29.23$ & 355 & $\$ 32.84$ & & \\
\hline Aug & & & 253 & $\$ 25.80$ & 444 & $\$ 44.58$ & 352 & $\$ 33.89$ & & \\
\hline Sep & & & 317 & $\$ 32.23$ & 407 & $\$ 40.91$ & 383 & $\$ 37.23$ & & \\
\hline Oct & & & 155 & $\$ 15.57$ & 398 & $\$ 39.71$ & 352 & $\$ 33.53$ & & \\
\hline Nov & & & 152 & $\$ 14.02$ & 163 & $\$ 15.42$ & 194 & $\$ 18.14$ & & \\
\hline Dec & & & 187 & $\$ 17.91$ & 185 & $\$ 16.85$ & 155 & $\$ 14.43$ & & \\
\hline Total & 0 & $\$ 0.00$ & 2546 & $\$ 251.51$ & 3429 & $\$ 331.18$ & 3095 & $\$ 287.63$ & 762 & $\$ 68.20$ \\
\hline Average & 0.00 & $\$ 0.00$ & 212.17 & $\$ 20.96$ & 285.75 & $\$ 27.60$ & 257.92 & $\$ 23.97$ & 190.5 & $\$ 17.05$ \\
\hline
\end{tabular}

Table 7. Electricity Consumption and Cost for CH1

\begin{tabular}{ccccccccccc}
\hline & \multicolumn{2}{c}{$\mathbf{2 0 1 3}$} & \multicolumn{2}{c}{$\mathbf{2 0 1 4}$} & \multicolumn{2}{c}{$\mathbf{2 0 1 5}$} & \multicolumn{2}{c}{$\mathbf{2 0 1 6}$} & \multicolumn{2}{c}{$\mathbf{2 0 1 7}$} \\
\cline { 2 - 10 } kWh & $\mathbf{C o s t} \mathbf{( \$ )}$ & $\mathbf{k W h}$ & $\mathbf{C o s t} \mathbf{( \$ )}$ & $\mathbf{k W h}$ & $\mathbf{C o s t} \mathbf{( \$ )}$ & $\mathbf{k W h}$ & $\mathbf{C o s t} \mathbf{( \$ )}$ & $\mathbf{k W h}$ & $\mathbf{C o s t}(\mathbf{\$ )}$ \\
\hline Jan & 589 & $\$ 52.30$ & 536 & $\$ 45.94$ & 546 & $\$ 48.70$ & 640 & $\$ 54.40$ & 642 & $\$ 49.50$ \\
Feb & 523 & $\$ 47.96$ & 605 & $\$ 53.54$ & 597 & $\$ 53.31$ & 661 & $\$ 55.92$ & 522 & $\$ 49.96$ \\
Mar & 345 & $\$ 31.71$ & 557 & $\$ 51.58$ & 509 & $\$ 45.45$ & 573 & $\$ 52.31$ & 639 & $\$ 60.45$ \\
Apr & 219 & $\$ 20.08$ & 353 & $\$ 36.04$ & 517 & $\$ 48.34$ & 436 & $\$ 39.98$ & 487 & $\$ 45.53$ \\
May & 142 & $\$ 13.77$ & 305 & $\$ 31.51$ & 430 & $\$ 42.14$ & 302 & $\$ 28.03$ & & \\
Jun & 304 & $\$ 29.49$ & 392 & $\$ 39.63$ & 392 & $\$ 36.77$ & 285 & $\$ 25.54$ & \\
Jul & 319 & $\$ 31.20$ & 510 & $\$ 51.92$ & 454 & $\$ 42.49$ & 438 & $\$ 39.68$ & \\
Aug & 233 & $\$ 22.74$ & 259 & $\$ 25.51$ & 398 & $\$ 38.65$ & 390 & $\$ 36.78$ & \\
Sep & 252 & $\$ 24.49$ & 288 & $\$ 28.28$ & 432 & $\$ 41.99$ & 362 & $\$ 34.46$ & \\
Oct & 193 & $\$ 18.68$ & 299 & $\$ 29.00$ & 449 & $\$ 43.33$ & 466 & $\$ 43.48$ & & \\
Nov & 300 & $\$ 27.57$ & 378 & $\$ 33.68$ & 534 & $\$ 48.86$ & 448 & $\$ 41.04$ & \\
Dec & 553 & $\$ 48.44$ & 524 & $\$ 48.47$ & 630 & $\$ 55.50$ & 596 & $\$ 54.36$ & \\
Total & 3,972 & $\$ 368.43$ & 5,006 & $\$ 475.10$ & 5,888 & $\$ 545.53$ & 5,597 & $\$ 505.98$ & 2290 & $\$ 205.44$ \\
Average & 331.0 & $\$ 30.70$ & 417.1 & $\$ 39.59$ & 490.7 & $\$ 45.46$ & 466.4 & $\$ 42.17$ & 572.5 & $\$ 51.36$ \\
\hline
\end{tabular}

\subsection{Case study 2}

This section details the information collected from GHP2 and CH2. This case study is a retrofit installation of a GHP system for a single-family home that, up until September 2014, utilized a conventional forced air HVAC system. Therefore, the data for comparison used included collecting consumption and usage cost data from prior to the installation of the GHP system (designated as CH2) and after the installation of the GHP system (designated as GHP2) are the same except for the electricity consumption and cost data.

GHP2 is a single-family residence built in 2000 and is located in a southern area of New Orleans, Louisiana. It is a two-story building with a floor area of $279 \mathrm{~m}^{2}\left(3,000 \mathrm{ft}^{2}\right)$. The home used a conventional split system air conditioning $(\mathrm{CH} 2)$ system for 14 years. Before this retrofit occurred, the homeowner decided to improve the core and shell (e.g., new insulation and windows) to increase the energy efficiency of the home. The home is also equipped with an intelligent thermostat controlling three zones. The ductwork for the geothermal heat pump system is the same as the original system with minor improvements to reduce duct leaks. Table 8 presents the building shell for GHP2 and CH2.

Table 8. Building shell information for Case Study 2

\begin{tabular}{lll}
\hline Shell & Materials & Insulation \\
\hline Exterior Walls & Brick, moisture membrane, 5.1cm by 15.2cm (2in by 6in) & Foam cellulose, \\
& wood studs, insulation & U-value=0.57 \\
Roof & Seal tab architectural shingles moisture membrane, OSB & Foam cellulose, \\
& sheathing, 5.1cm by 20.3cm (2in by 8in) rafters, insulation & U-value=0.30 \\
Windows & Low-E, vinyl double pane glass & U-value=0.71 \\
\hline
\end{tabular}


CH2 used a conventional air conditioning system until September 2014. The two-story building had a 16 SEER split system air conditioner using ductwork as the distribution system along with electric radiation heating. The conventional system provided seven tons of cooling to the $279 \mathrm{~m}^{2}$ house (Three tons for upstairs and four tons for downstairs). In October 2014, the homeowner replaced the conventional system with a GHP system (GHP2) that uses a vertical closed-loop heat exchanger configuration.

\subsubsection{Installation cost data}

The material and installation cost of the GHP system installed in GHP2 and CH2 were obtained from the homeowner and the company that performed the installation. The installation and equipment cost of the air-source system installed in $\mathrm{CH} 2$ includes cost data as provided by the homeowner along with the average cost calculated from three quotes requested from three different local mechanical contractors. Table 9 outlines the costs for the conventional HVAC system in CH2 and the GHP system in GHP2. With a total installation cost of \$42,098 and a total size of the house being $279 \mathrm{~m}^{2}\left(3,000 \mathrm{ft}^{2}\right)$ the GHP system cost $\$ 155.88 \mathrm{per} \mathrm{m}^{2}\left(\$ 14.03\right.$ per $\left.\mathrm{ft}^{2}\right)$ to install and the GHP system cost $\$ 17,588$ more to install than the conventional system.

Table 9. Installation cost for Case Study 2

GHP System (GHP2)

Total Cost

\begin{tabular}{lr}
\hline Equipment & \\
Geothermal Heat Pump (Water-to-air heat pump) & $\$ 19,198$ \\
Water pump & $\$ 1,200$ \\
Distribution system & $\$ 3,750$ \\
System controls & $\$ 4,200$ \\
Labor & Included above \\
Equipment Total & $\$ 28,348$ \\
\hline Drilling & $\$ 7,500$ \\
Grouting & $\$ 550$ \\
Lipes, fittings, and headers & $\$ 5,700$ \\
$\quad$ Ground Loop Total & Included above \\
Ground Loop & $\$ 13,750$ \\
\hline CHP2 SYSTEM TOTAL & $\mathbf{\$ 4 2 , 0 9 8}$ \\
\hline & $\mathbf{T o t a l ~ C o s t}$ \\
Equipment (Split system and radiation heating) & $\$ 11,831$ \\
Materials & $\$ 2,072$ \\
Distribution System & $\$ 3,808$ \\
Labor & $\$ 6,799$ \\
CH2 SYSTEM TOTAL & $\mathbf{\$ 2 4 , 5 1 0}$ \\
\hline
\end{tabular}

\subsubsection{Consumption and cost data}

The energy usage data collected for GHP2 and CH2 included data from monthly energy bills provided by the homeowner. The data includes 27 months of electricity consumption and related cost that represent $\mathrm{CH} 2$, from July 2012 through September 2014, which is when installation of the GHP system occurred. Then, the electricity consumption and costs for GHP2 were collected for 27 months after the installation, from October 2014 through December 2016. GHP2 and CH2 electricity consumption and costs are presented in Table 10 and Table 11, respectively. As the same as Case Study 1, the cost amounts included have been normalized to 2017 prices using inflation values from the U.S. Bureau of Labor Statistics, with 6.8\% inflation for 2012, 5.2\% for 2013, 3.5\% for 2014, 3.4\% for 2015, and 2.1\% for 2016. The total energy consumption from October 2014 to December 2016 for GHP2 is 39,440 kWh and the total usage cost is $\$ 3,737.45$. The total energy consumption from July 2012 to September 2014 for $\mathrm{CH} 2$ is $98,345 \mathrm{kWh}$ with a total usage cost of $\$ 9,532.22$. Furthermore, the homeowner reported keeping the indoor ambient temperature between $19.4^{\circ} \mathrm{C}\left(67^{\circ} \mathrm{F}\right)$ and $22.2^{\circ} \mathrm{C}\left(72^{\circ} \mathrm{F}\right)$ throughout the year.

\section{Analysis}

For energy and cost performance of GHP systems, installation cost, and electricity consumption and cost were collected from each of the residential homes used in the case study via monitoring systems and monthly electricity utility bills collected from the homeowners. The statistical analysis used for the collected consumption and cost data was the analysis of variance (ANOVA) test. In conducting an appropriate ANOVA, three tests must be completed, which includes analyzing the shape of the data (test for normality), the spread of the data (test for homogeneity of variance), and the location of the data (ANOVA test of means). 
Table 10. Energy Consumption and Usage Cost for GHP2

\begin{tabular}{|c|c|c|c|c|c|c|}
\hline & \multicolumn{2}{|c|}{2014} & \multicolumn{2}{|c|}{2015} & \multicolumn{2}{|c|}{2016} \\
\hline & kWh & Cost (\$) & kWh & Cost (\$) & kWh & Cost (\$) \\
\hline Jan & & & 1,760 & $\$ 162.33$ & 1,440 & $\$ 124.97$ \\
\hline Feb & & & 1,520 & $\$ 140.35$ & 1,520 & $\$ 131.29$ \\
\hline Mar & & & 1,600 & $\$ 147.74$ & 960 & $\$ 89.49$ \\
\hline Apr & & & 1,040 & $\$ 100.55$ & 960 & $\$ 89.88$ \\
\hline May & & & 960 & $\$ 97.28$ & 1,120 & $\$ 106.12$ \\
\hline Jun & & & 1,200 & $\$ 116.39$ & 1,520 & $\$ 139.05$ \\
\hline Jul & & & 1,520 & $\$ 147.11$ & 2,000 & $\$ 185.01$ \\
\hline Aug & & & 1,920 & $\$ 192.77$ & 2,320 & $\$ 223.37$ \\
\hline Sep & & & 1,760 & $\$ 176.89$ & 2,000 & $\$ 194.40$ \\
\hline Oct & 1,680 & $\$ 168.73$ & 1,280 & $\$ 127.72$ & 1,280 & $\$ 121.93$ \\
\hline Nov & 1,920 & $\$ 177.13$ & 960 & $\$ 90.83$ & 1,120 & $\$ 104.75$ \\
\hline Dec & 1,280 & $\$ 122.59$ & 960 & $\$ 87.45$ & 1,840 & $\$ 171.33$ \\
\hline Total & 4,880 & $\$ 468.45$ & 16,480 & $\$ 1,587.41$ & 18,080 & $\$ 1,681.59$ \\
\hline \multirow[t]{3}{*}{ Average } & $1,626.7$ & $\$ 156.15$ & 1373.3 & $\$ 132.28$ & 1506.7 & $\$ 140.13$ \\
\hline & \multicolumn{2}{|c|}{2012} & \multicolumn{2}{|c|}{2013} & \multicolumn{2}{|c|}{2014} \\
\hline & kWh & Cost (\$) & kWh & Cost (\$) & kWh & Cost (\$) \\
\hline Jan & & & 4,130 & $\$ 385.81$ & 3,980 & $\$ 366.47$ \\
\hline Feb & & & 3,560 & $\$ 343.43$ & 3,360 & $\$ 326.21$ \\
\hline Mar & & & 3,650 & $\$ 362.55$ & 3,750 & $\$ 359.54$ \\
\hline Apr & & & 2,770 & $\$ 235.38$ & 2,440 & $\$ 257.94$ \\
\hline May & & & 2,250 & $\$ 229.60$ & 2,040 & $\$ 240.65$ \\
\hline Jun & & & 2,820 & $\$ 287.76$ & 3,160 & $\$ 295.19$ \\
\hline Jul & 3,220 & $\$ 290.59$ & 3,560 & $\$ 366.27$ & 3,665 & $\$ 386.30$ \\
\hline Aug & 4,150 & $\$ 397.94$ & 4,500 & $\$ 462.04$ & 4,710 & $\$ 458.94$ \\
\hline Sep & 4,130 & $\$ 377.13$ & 3,920 & $\$ 422.31$ & 4,430 & $\$ 419.92$ \\
\hline Oct & 4,500 & $\$ 416.68$ & 4,430 & $\$ 458.25$ & & \\
\hline Nov & 4,500 & $\$ 402.74$ & 4,650 & $\$ 435.05$ & & \\
\hline Dec & 2,970 & $\$ 271.06$ & 3,000 & $\$ 276.47$ & & \\
\hline Total & 23,470 & $\$ 2,156.14$ & 43,240 & $\$ 4,264.92$ & 31,535 & $\$ 3,111.16$ \\
\hline Average & $3,911.7$ & $\$ 359.36$ & $3,603.3$ & $\$ 355.41$ & $3,503.9$ & $\$ 345.68$ \\
\hline
\end{tabular}

\subsection{Comparison of electricity consumption and cost for Case Study 1}

Using SPSS, Table 12 provides the descriptive statistics for the two homes in Case Study 1. In review of the descriptive statistics, GHP1 has a much lower average consumption and cost than CH1. The initial evidence shows that GHP1 uses less electricity that cost less to operate than $\mathrm{CH} 1$.

Table 12. Descriptive statistics of monthly electricity consumption and cost for in Case Study 1

\begin{tabular}{lcccccccc}
\hline & Case & Mean & $\begin{array}{c}\text { Standard } \\
\text { Deviation }\end{array}$ & Variance & Minimum & Maximum Range & N \\
\hline Electricity Consumption (kWh) & & & & & & & & \\
& GHP1 & 245.8 & 92.2 & $8,501.8$ & 123 & 444 & 321 & 40 \\
& CH1 & 437.6 & 134.1 & $18,011.2$ & 142 & 661 & 519 & 52 \\
\hline Electricity Cost (US \$) & & & & & & & & \\
& GHP1 & $\$ 23.46$ & $\$ 8.97$ & $\$ 80.54$ & $\$ 12.92$ & $\$ 44.58$ & $\$ 31.66$ & 40 \\
& $\mathrm{CH} 1$ & $\$ 40.39$ & $\$ 11.45$ & $\$ 131.03$ & $\$ 14.49$ & $\$ 60.45$ & $\$ 45.96$ & 52 \\
\hline
\end{tabular}

\subsubsection{Analysis of variance (ANOVA) for Case Study 1}

The test for normality requires the review of the skewness and kurtosis of the data to determine if the data is normally distributed. Using the MVP Stats statistical program, the skewness and kurtosis values were calculated and presented in Table 13. Based on the results, the electricity consumption and cost data are approximately normally distributed as the p-values are greater than 0.05 for skewness and kurtosis for GHP1 and CH1. 
Table 13. ANOVA results for in Case Study 1

\begin{tabular}{|c|c|c|c|c|c|c|c|c|c|}
\hline \multirow[b]{2}{*}{ Category } & \multirow[b]{2}{*}{ Case } & \multicolumn{4}{|c|}{ Test for Normality } & \multicolumn{2}{|c|}{$\begin{array}{l}\text { Homogeneity of } \\
\text { Variance Test }\end{array}$} & \multicolumn{2}{|c|}{$\begin{array}{l}\text { One-Way ANOVA of } \\
\text { the Means }\end{array}$} \\
\hline & & Skewness & p-value & Kurtosis & p-value & $\begin{array}{l}\text { Levene's } \\
\text { Statistic }\end{array}$ & p-value & F-Test & p-value \\
\hline \multicolumn{10}{|c|}{ Electricity Consumption } \\
\hline & GHP1 & 0.649 & 0.083 & -0.809 & $>0.10$ & & & & \\
\hline & $\mathrm{CH} 1$ & 0.765 & 0.051 & -0.540 & $>0.10$ & 7.446 & 0.008 & 65.790 & 0.000 \\
\hline \multicolumn{10}{|c|}{ Electricity Cost } \\
\hline & GHP1 & -0.197 & 0.535 & -0.915 & $>0.10$ & 3356 & 070 & 68475 & مOח \\
\hline & CH1 & -0.410 & 0.205 & -0.761 & $>0.10$ & 3.356 & 0.070 & 68.475 & \\
\hline
\end{tabular}

By establishing normality, the homogeneity of variance was analyzed using Levene's Statistic for the energy consumption data based on the absolute deviation from the average (ADAs) values. The results of the homogeneity of variance test for electricity consumption is significant at the 0.05 level as shown in Table 13, meaning the variances are statistically different between GHP1 and CH1 for electricity consumption. The point estimates for the variance of monthly electricity consumption are 8,501.81 kWh for GHP1 and 18,011.15 kWh for CH1, meaning the conventional home in this case study had a higher variance in their electricity use than the home using the GHP system. On the other hand, for the homogeneity of variance test for electricity cost, the results are not significant at the 0.05 level, meaning the variance in electricity cost are statistically the same between GHP1 and $\mathrm{CH} 1$, which is calculated by taking the average of the variances from GHP1 and CH1 that equals \$105.77.

Then, due to unequal variances, the ANOVA of the means for the electricity consumption data was conducted using Welch's statistic. Welch's statistic is a form of ANOVA that is robust to lack of homogeneity of variance by using an asymptotically distributed F-test. The results of the Welch ANOVA is statistically significant $(p=$ 0.000), meaning the average electricity consumption is different between GHP1 and CH1 and the point estimates for average monthly electricity consumption are $437.56 \mathrm{kWh}$ for GHP1 and $245.80 \mathrm{kWh}$ for CH1, which is $44 \%$ less electricity consumption by the GHP1 system over the CH1 system.

Next, the results of the ANOVA of the means for GHP1 and CH1 for electricity cost is an F-test value of 68.475 with a p-value of 0.000 . With the p-value less than 0.05 , the results show that average electricity cost is not statistically equal between GHP1 and CH1. Therefore, the point estimates for the average monthly electricity cost are \$23.46 for GHP1 and \$40.39 for CH1, which shows electricity consumption is $42 \%$ less a month for GHP1.

\subsubsection{Payback period for Case Study 1}

The average monthly cost of electricity for GHP1 is less than CH1, which should be expected since the GHP is a more efficient system than an ASHP conventional system. To calculate the payback period, the difference in installation costs between GHP1 and CH1, which is $\$ 14,149$, is divided by the annual savings. Table 14 shows the calculation for annual savings. Equation 1 shows the payback period for GHP1.

$$
\text { Payback Period }=\frac{\$ 14,149}{\$ 194.42}=72.8 \text { years }
$$

Table 14. Monthly electricity cost savings between GHP1 and CH1.

\begin{tabular}{cccc}
\hline & GHP1 Avg Monthly Cost & CH1 Avg Monthly Cost & Monthly Savings \\
\hline Jan & $\$ 20.10$ & $\$ 50.17$ & $\$ 30.07$ \\
Feb & $\$ 29.96$ & $\$ 52.14$ & $\$ 22.18$ \\
Mar & $\$ 22.61$ & $\$ 48.30$ & $\$ 25.70$ \\
Apr & $\$ 15.22$ & $\$ 37.99$ & $\$ 22.77$ \\
May & $\$ 15.33$ & $\$ 28.86$ & $\$ 13.53$ \\
Jun & $\$ 18.57$ & $\$ 32.86$ & $\$ 14.28$ \\
Jul & $\$ 28.35$ & $\$ 41.32$ & $\$ 12.97$ \\
Aug & $\$ 34.76$ & $\$ 30.92$ & $-\$ 3.84$ \\
Sep & $\$ 36.79$ & $\$ 32.31$ & $-\$ 4.48$ \\
Oct & $\$ 29.60$ & $\$ 33.62$ & $\$ 4.02$ \\
Nov & $\$ 15.86$ & $\$ 37.79$ & $\$ 21.93$ \\
Dec & $\$ 16.40$ & $\$ 51.69$ & $\$ 35.30$ \\
Total & $\$ \mathbf{2 8 3 . 5 5}$ & $\mathbf{\$ 4 7 7 . 9 7}$ & $\mathbf{\$ 1 9 4 . 4 2}$ \\
\hline
\end{tabular}




\subsection{Comparison of electricity consumption and cost for Case Study 2}

Table 15 provides the descriptive statistics for the Case Study 2 retrofit home. In review of the descriptive statistics, GHP2 has a much lower average electricity consumption and cost than $\mathrm{CH} 2$. The sections below outline the results of the ANOVA for comparing GHP2 before and after retrofitting the home with the GHP system.

Table 15. Descriptive statistics of the monthly electricity consumption and cost for Case Study 2

\begin{tabular}{lccccccccc}
\hline & House & Mean & $\begin{array}{c}\text { Standard } \\
\text { Deviation }\end{array}$ & Variance & Minimum & Maximum & Range & N \\
\hline Electricity Consumption & & & & & & & & \\
& GHP2 & $1,460.7$ & 391.0 & $152,907.1$ & 960 & 2,320 & 1,360 & 27 \\
\hline Electricity Cost & CH2 & $3,638.7$ & 767.0 & $588,345.3$ & 2,040 & 4,710 & 2,670 & 27 \\
\hline & GHP2 & $\$ 138.42$ & $\$ 37.96$ & $\$ 1,440.92$ & $\$ 87.45$ & $\$ 223.37$ & $\$ 135.92$ & 27 \\
& CH2 & $\$ 353.05$ & $\$ 72.75$ & $\$ 5,292.58$ & $\$ 229.60$ & $\$ 462.04$ & $\$ 232.44$ & 27 \\
\hline
\end{tabular}

\subsubsection{Analysis of variance (ANOVA) for Case Study 2}

The test for normality requires the review of the skewness and kurtosis of the Case Study 2 data to determine if the data is normally distributed. Using the MVP Stats statistical program, the skewness and kurtosis values were calculated and presented in Table 16. Based on the results, the data for electricity consumption and electricity cost are approximately normally distributed as the p-values are greater than 0.05 for skewness and kurtosis for GHP2 and $\mathrm{CH} 2$.

Table 16. ANOVA results for Case Study 2

\begin{tabular}{|c|c|c|c|c|c|c|c|c|c|}
\hline & \multicolumn{4}{|c|}{ Test for Normality } & \multicolumn{3}{|c|}{$\begin{array}{l}\text { Homogeneity of } \\
\text { Variance Test }\end{array}$} & \multicolumn{2}{|c|}{$\begin{array}{l}\text { One-Way ANOVA } \\
\text { of the Means }\end{array}$} \\
\hline & Case & Skewness & p-value & Kurtosis & p-value & $\begin{array}{c}\text { Levene's } \\
\text { Statistic }\end{array}$ & p-value & F-Test & p-value \\
\hline \multicolumn{10}{|c|}{ Electricity Consumption } \\
\hline & $\begin{array}{c}\text { GHP2 } \\
\text { CH2 }\end{array}$ & $\begin{array}{l}0.311 \\
0.420 \\
\end{array}$ & $\begin{array}{l}0.467 \\
0.330 \\
\end{array}$ & $\begin{array}{l}-0.845 \\
-0.743 \\
\end{array}$ & $\begin{array}{l}>0.10 \\
>0.10 \\
\end{array}$ & 10.988 & 0.002 & 174.039 & 0.000 \\
\hline \multicolumn{10}{|c|}{ Electricity Cost } \\
\hline & $\begin{array}{l}\text { GHP2 } \\
\text { CH2 }\end{array}$ & $\begin{array}{l}-0.462 \\
-0.313\end{array}$ & $\begin{array}{l}0.286 \\
0.465\end{array}$ & $\begin{array}{l}-0.716 \\
-1.100\end{array}$ & $\begin{array}{l}>0.10 \\
>0.10\end{array}$ & 15.471 & 0.000 & 164.161 & 0.000 \\
\hline
\end{tabular}

Establishing normality means that the homogeneity of variance was analyzed using Levene's Statistic for electricity consumption and use based on the absolute deviation from the average values (ADAs), which were calculated in MVP Stats and transferred to SPSS to conduct the homogeneity of variance test. The homogeneity of variance test for electricity consumption and cost shown in Table 16 are statistically significant at the 0.05 level. The statistically significant results at 0.05 mean that the variances are statistically not the same in Case Study 2 for electricity consumption an electricity cost. The point estimates for variance in electricity consumption are $152,907.12 \mathrm{kWh}$ for GHP2 and 588,345.37 kWh for CH2, showing that the conventional system has a much higher variability in their consumption. The point estimates for variance in electricity cost are $\$ 1,440.92$ for GHP2 and $\$ 4,785.20$ for $\mathrm{CH} 2$, again a higher variance in cost for the conventional system.

With normality and homogeneity of variance tested, a one-way ANOVA of the means was performed using Welch's Test. For electricity consumption, the F-test value is 174.039 with a p-value of 0.000 , while the results for electricity cost is a F-test value of 164.161 with a p-value of 0.000 . With both p-values less than 0.05 , the results show that average monthly electricity consumption and cost are not equal for GHP2 and CH2. Therefore, the point estimate monthly average electricity consumption for GHP2 is $1,460.74 \mathrm{kWh}$, while the point estimate for $\mathrm{CH} 2$ is 3,638.70 kWh, which is 59\% less consumption for GHP2 over CH2. The point estimate for the average monthly electricity usage cost is $\$ 138.42$ for GHP2 and $\$ 336.21$ for $\mathrm{CH} 2$, which means the GHP system saves the homeowner $59 \%$ or $\$ 197.79$ a month on electricity costs (\$2,373.48 annually) over the original HVAC system.

\subsubsection{Payback period for Case Study 2}

For Case Study 2, as also seen with Case Study 1, the electricity costs are less when operating a GHP system over a conventional HVAC system, but the installation costs were much higher. To find the payback period for the additional installation costs needed for the GHP system, the difference in installation costs, which is $\$ 17,588$, is divided by the annual savings, which were calculated in Table 17. Equation 2 presents the payback period for Case Study 2. 
Payback Period $=\frac{\$ 17,588}{\$ 2,495.88}=7.05$ years

Table 17. Monthly electricity cost savings between GHP2 and CH2.

\begin{tabular}{cccc}
\hline & GHP2 Avg Monthly Cost & CH2 Avg Monthly Cost & Monthly Savings \\
\hline Jan & $\$ 143.65$ & $\$ 376.14$ & $\$ 232.49$ \\
Feb & $\$ 135.82$ & $\$ 334.82$ & $\$ 199.00$ \\
Mar & $\$ 118.62$ & $\$ 361.05$ & $\$ 242.43$ \\
Apr & $\$ 95.22$ & $\$ 246.66$ & $\$ 151.45$ \\
May & $\$ 101.70$ & $\$ 235.13$ & $\$ 133.43$ \\
Jun & $\$ 127.72$ & $\$ 291.48$ & $\$ 163.76$ \\
Jul & $\$ 166.06$ & $\$ 347.72$ & $\$ 181.66$ \\
Aug & $\$ 208.07$ & $\$ 439.64$ & $\$ 231.57$ \\
Sep & $\$ 185.65$ & $\$ 406.45$ & $\$ 220.81$ \\
Oct & $\$ 139.46$ & $\$ 437.47$ & $\$ 298.01$ \\
Nov & $\$ 124.24$ & $\$ 418.90$ & $\$ 294.66$ \\
Dec & $\$ 127.12$ & $\$ 273.77$ & $\$ 146.64$ \\
Total & $\$ \mathbf{1 , 6 7 3 . 3 2}$ & $\mathbf{\$ 4 , 1 6 9 . 2 0}$ & $\mathbf{\$ 2 . 4 9 5 . 8 9}$ \\
\hline
\end{tabular}

\section{Discussion}

Throughout this investigation, the lack of knowledge in GHP systems became evident in Louisiana. Few HVAC contractors seemed to be familiarized with non-traditional systems and even fewer were experienced GHP installers. The GHP market in southern Louisiana is currently shared by only a handful of contractors. In the middle of this incredible low market competition, this study was able to collect cost and performance data from two case studies. The case studies had differing results, with one being new construction that showed small annual savings and very long payback period, and the other being a retrofit of an existing home that showed much higher savings and a more reasonable payback period.

\subsection{Case study 1 (GHP1 and CH1)}

This case study presents an expensive GHP system installation relative to the building square footage. More than $50 \%$ of the total GHP system cost belongs to the interior components. Within these interior components, the GHP equipment itself represents nearly half of the HVAC system cost. Since this residence was new construction, the ductwork also represents a sizable portion of the cost. The third major expense comes from the system controls. The owners of GHP1 have access to an online database that monitors utility consumption/production daily. Thus, GHP1 system controls are more sophisticated than most homes. Also, the GHP system design includes a cooling tower, which increased the complexity of the design and the cost (extra piping, more equipment, labor, etc.) While the design included the cooling tower to help increase the cooling load capacity, the homeowner realized that the cooling tower was an unnecessary expense for such a relatively small square footage single-family home. Larger applications benefit from the use of cooling towers but tend to be unnecessary for smaller residential applications.

This GHP system had technical issues after three years of being in operation, which required maintenance and inspection from a third party who not involved at the time of design and installation. While it is highly recommended the design and installation of GHP systems to be a single party job [32], in this case multiple parties were involved. The design drawings were developed by a mechanical engineering group, the excavation and ground loop installation were done by two different small contracting companies, the HVAC was installed by a local contractor, and the architect, who was involved in the building's construction. In discussions with the homeowner, amount of parties involved combined with a steep learning curve (first GHP installation) and lack of certified and experienced designers and installers involved in the project negatively affected the "team" relationship and it was ultimately reflected on the high system cost and less than ideal performance.

When comparing GHP1 to CH1, which uses an air-source heat pump conventional heating and cooling system, it was no surprise the stark difference on installation cost. The savings in utility services, on the other hand, were as expected. But even though utility monthly expenses are half of CH1 expenses, the payback period of GHP1 is 72 years. The extensive payback period is a result of multiple parties involved in the design and installation, the inclusion of unnecessary components (e.g., cooling tower), the use of a horizontal heat exchanger loop, and a lack of understanding to design and install a proper GHP system in hot and humid climates All these factors negatively affected the installation and performance of the system and these are common factors that need to be considered during the design and installation of GHP systems for homes [4,21]. 


\subsection{Case study 2 (GHP2 and CH2)}

Case study 2 was an existing home with a retrofitted GHP. The interior components of the GHP system account for more than half of the total project cost as the heat pump and system controls are the largest expenses of the interior components. The capacity of the heat pump is slightly on the heavier side for a residential dwelling (7 tons) to account for the higher cooling loads in a hot and humid climate and the home uses a three-zone intelligent thermostat.

The difference in electricity bills before and after GHP installation showed a decrease of $59 \%$ in electricity bills. Furthermore, in discussions with the homeowner, satisfaction with the GHP system was very high. The decrease in electricity costs is comparable to the $50 \%$ savings stated by Cooperman et al. [4].

It is important to mention that the homeowner conducted their own extensive research before making their choice to hire an installation firm and purchase the GHP system. The designer and installer of the GHP system for the retrofitted home is a certified IGSHPA contractor and has over 30 years of experience with designing and installing conventional and geothermal HVAC systems. Case Study 2 demonstrates that a well-educated owner along with employing a certified geothermal designer and installer positively impact the electricity use and cost savings realized in using a GHP system. Case Study 2 shows that GHP systems can be retrofitted to existing homes and can perform well in hot and humid climates, as long as a properly certified and experienced designer and installer is hired to perform the work, as has been stated in previous sources $[6,15,18,19]$. Overall, the evidence from case study 2 proves that GHPs can work for residences located in hot and humid climates.

\subsection{Comparison of the two case studies}

Case Study 1 included new construction of two similar homes, except one used a GHP system and the other used an air-source heat pump conventional system. Case Study 2 included the retrofitting of a GHP system to a home built in the year 2000 that originally included a conventional system. In terms of installation costs, GHP2 cost more than GHP1, but GHP2 is a much larger home, more than twice the square footage of GHP1. However, the cost per SF for GHP2 was much lower than GHP1. For cost savings in operating a GHP over a conventional system, GHP2 had a much higher annual savings than GHP1. Therefore, the higher installation cost per SF and lower cost savings for GHP1 results in a payback period of over 70 years. The payback period is longer than the life of a GHP system as the components and equipment last between 20 years (e.g., ground source heat pump) and 50 years (e.g., ground loop). The payback periods for the two case studies are comparable to previous studies, and when compared to Cooperman et al. [4] that found payback periods for GHPs for residences in the southern US to be in the range of 10 to more than 30 years while Cui et al. [7] found the payback period to be more than 15 years. Therefore, while payback period results for Case Study 1 are on the higher end, Case Study 2 is on the lower end and provides viable evidence that GHP systems can be economically beneficial in hot and humid climate regions.

The installation process was key to each case. A GHP system cost and performance are directly impacted by using a designer and installer that has the proper GHP system certification and experience. In the case of GHP1, the multiple parties involved, the lack of certified and experience parties involved, and the overdesign and inclusion of unnecessary components drastically increased the installation cost to a point that the payback on the investment makes the investment look as though it was not worth it. Furthermore, the inability to provide a vertical heat exchanger loop at the site impacted and lessened the savings. The horizontal slinky loop used was only $1.2 \mathrm{~m}$ to $1.8 \mathrm{~m}$ below the ground level. The heat in the ground at this depth varies from $12^{\circ} \mathrm{C}$ to $31^{\circ} \mathrm{C}$ while the $76 \mathrm{~m}$ deep boreholes used in the GHP2 home reach more constant temperatures of about $20^{\circ} \mathrm{C}$. The GHP1 system with a horizontal heat exchanger loop is less efficient than the GHP2 system with a vertical heat exchanger loop, making the case that GHP systems in hot and humid climates benefit more from vertical ground loops than horizontal loops.

The data also shows that due to the installation costs for a GHP system, smaller homes do not experience the same cost benefits as larger homes. Although the GHP1 system may not have been designed or installed ideally, the cost per SF is more than GHP2 due to the smaller size of GHP1. Zhu et al., [8] pointed out that smaller facilities have more uncertainties in the cost and energy savings associated with GHP systems due to the economies of scale in terms of the equipment cost and heat exchanger loop costs, which increases the payback period. More research is needed to determine how to make small scale GHP systems more cost efficient and better performing that results in a shorter payback period for smaller residential homes located in hot and humid climate zones.

\section{Conclusion}

This study collected electricity consumption and cost data from two residential buildings in southern Louisiana with GHP systems installed for heating and cooling. One home was new construction and one was an existing home retrofitted with a GHP system. For the new construction building, data was collected from another home with matching characteristics that has an installed conventional HVAC system was collected. Based on the findings, the initial cost of a GHP system is approximately twice the initial cost of a conventional HVAC system, 
which is a detriment to people that would like to install a GHP system. Yet, electricity use and cost can be $59 \%$ less with GHPs than a conventional HVAC system. Additionally, the payback period of a GHP system with a vertical ground heat exchanger loop installed in an average size household in southern Louisiana is comparable to residences in cooler climates. However, the design and contractor base for GHPs in southern Louisiana is in its infancy, which can lead to systems not performing well or costing more than expected.

Human factors and the use of the case study homes varied, meaning that slight differences existed between the GHP homes and conventional HVAC homes even though the physical building structures of the cases were similar. As is common in case study research, factors such as when people decide to turn on or off their HVAC system, are difficult to control. Another limitation was the low number of GHP system installers available in southern Louisiana along with a lack of willingness to share itemized cost information for this research study. A limited amount of GHP system contractors exist within Louisiana, and of these contractors, most were not willing to share data than the contractors that did share their data for this research. This limitation dictated which case studies could be investigated fully in this study.

The opportunities for research in GHPs are numerous. GHPs are more popular in more moderate climate areas of the U.S. where the heating loads are equal to or more than cooling loads and fossil fuel derivatives are more expensive. Research efforts have been done in order to increase awareness on the residential applications of GHPs in hot/humid climates, but very few have used real field data to compare the cost and performance of GHPs with other types of HVAC systems such as this study. One area to continue to investigate is the current geothermal energy market in southern Louisiana as there seems to be a lack of policies or regulations in place for GHP systems as well as a lack of knowledge and experience with GHP systems for hot and humid climates. In order to increase the use of GHP systems, especially for hot and humid climate zones, the economic conditions need to be further investigated.

\section{Acknowledgements}

The authors would like to thank the homeowners and contractors for their participation in providing data and allowing the research team to observe their homes on a regular basis.

\section{References}

[1] U.S. Department of Energy. Buildings energy data book. Office of Energy Efficiency and Renewable Energy, Buildings Technologies Program, Silver Spring, MD. 2012;286p. Available from: https://openei.org/doeopendata/dataset/buildings-energy-data-book

[2] U.S. Energy Information Administration. Total energy, Independent statistics and analysis. U.S. Department of Energy. 2020. Available from: https://www.eia.gov/totalenergy/data/browser/?tbl=T02.02\#/?f=A\&start $=1949 \&$ \&end=2019\&charted=2-3-4-10-12

[3] American Physical Society. Energy future: Think efficiency: How America can look within to achieve energy security and reduce global warming. Energy Efficiency Report. 2008 Sep;112p.

[4] Cooperman A, Dieckmann J, Brodrick J. Residential GSHPs: Efficiency with short payback periods. ASHRAE Journal. 2012;72-79.

[5] Goetzler W, Guernsey M, Kar R. Research and development roadmap: Geothermal (ground-source) heat pumps. U.S. Department of Energy, Office of Energy Efficiency and Renewable Energy, Building Technologies Program. October 2012;49p.

[6] Wiryadinata S, Modera M, Jenkins B, Kornbluth K. Technical and economic feasibility of unitary, horizontal ground-loop geothermal heat pumps for space conditioning in select California climate zones. Energy and Buildings. 2016;119:164-172. Available from: https://doi.org/10.1016/j.enbuild.2016.03.032

[7] Cui Y, Zhu J, Twaha S, Chu J, Bai H, Huan K, Chen X, Zoras S, Soleimani Z. Techno-economic assessment of the horizontal geothermal heat pump systems: A comprehensive review. Energy Conversion and Management. 2019;101:208-236. Available from: https://doi.org/10.1016/j.enconman.2019.04.018

[8] Zhu Y, Rayegan R, Tao Y. Case study of ground-source heat pump applications in hot and humid climates. ASCE Journal of Architectural Engineering, 2015;21(1). Available from: https://doi.org/10.1061 /(ASCE)AE.1943-5568.0000155

[9] Goetzler W, Guernsey M, Young J. Research and development roadmap for emerging HVAC technologies. U.S. Department of Energy, Office of Energy Efficiency and Renewable Energy, Building Technologies Office. 2014 Oct;121p.

[10] Garber D, Choudhary R, Soga K. Risk based costs assessment of a ground source heat pump (GSHP) system design: Methodology and case study. Building \& Environment. 2013;60:66-80. Available from: https://doi.org/10.1016/j.buildenv.2012.11.011 
[11] Hughes P. Geothermal (ground-source) heat pumps: Market status, barriers to adoption, and actions to overcome barriers. Technical report ORNL/TM-2008/232, Oak Ridge National Laboratory, U.S. Department of Energy, Office of Energy Efficiency and Renewable Energy, Geothermal Technologies Office. 2008 Dec; 46p.

[12] Valizade L. Ground source heat pumps. Journal of Clean Technologies. 2013;1(3):216-219. Available from: https://doi.org/10.7763/JOCET.2013.V1.49

[13] Christodoulides P, Aresti L, Florides G. Air-conditioning of a typical house in moderate climates with ground source heat pumps and cost comparison with air source hear pumps. Journal of Applied Thermal Engineering. 2019;158:113772. Available from: https://doi.org/10.1016/j.applthermaleng.2019.113772

[14] Yin P, Pate M, Battaglia F. In-field performance evaluation and economic analysis of residential ground source heat pumps in heating operations. Journal of Building Engineering. 2019;26:100932. Available from: https://doi.org/10.1016/j.jobe.2019.100932

[15] Liu X. Assessment of national benefits from retrofitting existing single-family homes with ground source heat pump systems. Technical report ORNL/TM-2010/122, Oak Ridge National Laboratory, U.S. Department of Energy. 2010 Sep;62p.

[16] Rybach L. New developments in geothermal heat pumps - with a view to the Swiss success story. Journal of the Geothermal Research Society of Japan. 2012;35(1):35-40. Available from: https://doi.org/10.11367/ GRSJ.35.35

[17] Bolling A, Mathias J. Investigation of optimal heating and cooling systems in residential buildings. ASHRAE Transactions. 2008:128-139. Available from: https://opensiuc.lib.siu.edu/meep_articles/2/

[18] Liu X, Lu S, Hughes P, Cai Z. A comparative study of the status of GSHP applications in the United States and China. Renewable and Sustainable Energy Reviews. 2015;(48):558-570. Available from: https://doi.org/10.1016/j.rser.2015.04.035

[19] Louisiana Department of Natural Resources. Heating, ventilation, and air conditioning. In: Guide to energy efficient homes in Louisiana. Technology Assessment Division, State of Louisiana. 2010;123-142. Chapter 7. Available from: http://www.dnr.louisiana.gov/assets/tad/builders_guide/Chapter_07.pdf.

[20] Healy P, Ugursal V. Performance and economic feasibility of ground source heat pumps in cold climate. International Journal of Energy Research. 1997;21:857-870. Available from: https://doi.org/10.1002/(SICI) 1099-114X(199708)21:10\%3C857::AID-ER279\%3E3.0.CO;2-1

[21] Nakagawa M, Reed A, Fujiono H, McCartney J. Recovery act - geothermal technologies program: Ground source heat pumps. Final Report DE-FOA-000116, CFDA Number 81.087, U.S. Department of Energy. 2011 Oct; 114p. Available from: https://doi.org/10.2172/1045164

[22] Blumsack S, Brownson J, Witmer L. Efficiency, economic and environmental assessment of ground-source heat pumps in central Pennsylvania. In: Annual Hawaii International Conference on System Sciences. University of Hawaii. 2009. Available from: https://doi.org/10.1109/HICSS.2009.179

[23] Catan M, Baxter V. An optimized ground coupled heat pump systems design for northern climate applications. ASHRAE Transactions. 1985;91(2B):1185-1203.

[24] Hughes P, Shonder, J. The evaluation of a 4000-home geothermal heat pump retrofit at Fort Polk, Louisiana: Final report. Technical report ORNL/CON-640, Oak Ridge National Laboratory, U.S. Department of Energy, Office of Energy Efficiency and Renewable Energy, Geothermal Technologies Office. 1998 Mar;163p. Available from: https://doi.org/10.2172/638196

[25] Tambe V, Reddy T, Kavazanjian E. The economic viability of ground couple heat pump systems in hot and semi-arid climate. In: Second Pan-American Conference on Unsaturated Soils. American Society of Civil Engineers. 2017 Nov. Available from: https://doi.org/10.1061/9780784481691.040

[26] Widiatmojo A, Chokchai S, Takashima I, Uchida Y, Yasukawa K, Chotpantarat S, Charusiri P. GroundSource Heat Pumps with Horizontal Heat Exchangers for Space Cooling in the Hot Tropical Climate of Thailand. Energies. 2019;12(7):1274. Available from: http://dx.doi.org/10.3390/en12071274

[27] Cane D, Morrison A, Ireland C, Garnet J. Survey and analysis of maintenance and service costs in commercial building geothermal systems. Geothermal Heat Pump Consortium. 1998.

[28] Tao Y, Zhu Y. Analysis of energy, environmental and life cycle cost reduction potential of ground source heat pump (GSHP) in hot and humid climate. Final Report DE-EE0002802, U.S. Department of Energy. 2012;204p. Available from: https://doi.org/10.2172/1039050

[29] NOAA. Data tools: Local Climatological Data (LCD). National Centers for Environmental Information, National Oceanic and Atmospheric Administration. Available from: https:/www.ncdc.noaa.gov/cdoweb/datatools/lcd

[30] Hillel D. Introduction to soil physics. Academic Press. 1982.

[31] U.S. Energy Information Administration. Electricity data browser, Louisiana average retail price for electricity. Available from: https://www.eia.gov/electricity/data/browser/\#/topic/7?agg=0,1\&geo=00000 
00008\&endsec=8\&freq=M\&start=200101\&end=201701\&ctype=linechart\&ltype=pin\&rtype=s\&pin=\&rse= 0\&maptype $=0$

[32] Konrad T. How geothermal heat pumps can soar like solar. Forbes Magazine. 2014 Feb. Available from: https://www.forbes.com/sites/tomkonrad/2014/02/28/how-geothermal-heat-pumps-can-soar-like-solar/?sh= 3e36d2bf1abd

(C) 2021 by the author(s). This work is licensed under a Creative Commons Attribution 4.0 International License (http://creativecommons.org/licenses/by/4.0/). Authors retain copyright of their work, with first publication rights granted to Tech Reviews Ltd. 